\title{
Management of white fly, Bemisia tabaci (Gennadius) through seed treatment in moth bean
}

\author{
B.L Jakhar*, Bindu Panickar and Y. Ravindrababu \\ Pulses Research Station, S.D. Agricultural University, Sardarkrushinagar-385 506 (Gujarat), INDIA \\ "Corresponding author. Email: bjakhar@rediffmail.com \\ Received: September 22, 2015; Revised received: March 10, 2016; Accepted: May 28, 2016
}

\begin{abstract}
A seed treatment trial was conducted at research farm of Centre of Excellence for Research on Pulses, S. D. Agricultural University, Sardarkrushinagar. The experiment was conducted for the control of white fly by seed treatment, four insecticides were used for seed treatment with two different doses of each insecticides viz., Bifenthrin 10 EC, Imidacloprid 600FS, Thiomethoxam 35 FS and Fipronil 5\%SC, these treatments were found significantly (at $5 \%$ ) superior over the control in reducing the white fly population in moth bean. The seed treatment with Thiomethoxam35 FS @5g/kg seeds found minimum white fly, Bemisia tabaci population (0.32 /leaf) followed by Imidacloprid600FS @ $5 \mathrm{~g} / \mathrm{kg}$ seeds (white fly 0.39/leaf) and maximum was recorded in control ( 1.06/leaf. Farmers are advised to use seed treatments with Thiomethoxam35 FS @ $5 \mathrm{~g} / \mathrm{kg}$ seeds or Imidacloprid 600FS @ 5 g/kg seeds before the sowing of moth bean crop for the control of white fly.
\end{abstract}

Keywords: Bifenthrin Fipronil, Hite fly, Imidacloprid, Moth bean, Seed treatment, Sucking pest, Thiomethoxam

\section{INTRODUCTION}

Mothbean, Vigna acontifolia (Jacg) Marechal is an important crop of dry and semi dry areas of India and some countries of Asia. Among Kharif pulses, it has the maximum capacity to resist drought conditions. Plants cover large area on the surface, conserve moisture and also protect the soil from erosion. Moth bean is mainly used as 'dal' and Bhujia preparations. Green pods are used as vegetable. India has the major area under moth bean in the world. Therefore about 23.47 M ha (Anonymous, 2013) of land have been under cultivation of pulses with an annual production of about 19.27 MT (Anonymous, 2014) In India, moth bean is mainly grown in Rajasthan and Gujarat which covers an area of about $0.92 \mathrm{M}$ ha which yields about 0.26 MT annually with the productivity of $388 \mathrm{~kg} / \mathrm{ha}$ (Anonymous, 2014). The moth bean crop is infested by several insect-pests right from germination to harvesting. Among these the white grub, Holotrichia consanguinea; termite, Odontotermes obesus; jassids, Empoasca motti; whitefly, Bemisia tabaci; galerucid beetle, Madursia obscurella; thrips, Caliothrips indicus; stem fly, Ophiomyia phaseoli; red hairy caterpillar, Amsacta moorei; flea beetle, Phyllotreata cruciferae; grey weevil, Myllocerus spp. and pod borer, Catechrysops cnejus posses greater threat to moth bean crop (Pareek et al., 1983). Among these, white fly is a major sucking pest cause moderate to severe damage starting right from germination to maturity of the crop and bring considerable decrease in yield
(Puttaswami et al., 1977). All sucking insects generally appear on the tender parts of the pant such as young leaves and flowers. Both nymphs and adults of insects suck the cell sap from leaves, flowers and other tender parts of plant and also playing role of a vector of YSo far no information is available on the management of white fly, Bemisia ta baci trough seed treatment in moth bean. Hence, present study was conducted to manage the white fly, Bemisia tabaci with different seed treatmentsin moth bean. Hence, present study was conducted to manage the white fly, Bemisia tabaci with different seed treatments.

\section{MATERIALS AND METHODS}

An experiment was conducted at Centre of Excellence for Research on Pulses, S. D. Agricultural University, Sardarkrushinagar during Kharif, 201213, 2013-14and 2014-15. The experiment was laidout in randomized block design with three replications and nine treatments viz., T1: Bifenthrin 10 EC@ 2 ml/kg seeds,T2: Bifenthrin 10 EC@ 4 ml/kg seeds,T3: Imidacloprid600FS@3 g/kg seeds, T4: Imidacloprid600FS@ $5 \mathrm{~g} / \mathrm{kg}$ seeds,T5: Thiomethoxam 35 FS@3g/kg seeds,T6: Thiomethoxam 35 FS@5g/kg seeds,T7: Fipronil 5\%SC@ 2 ml $/ \mathrm{kg}$ seeds,T8: Fipronil 5\%SC@4 ml/kg seeds and T9: Untreated control. All the agronomic practices were followed for raising the crop. Seed treatment from different insecticides was done before sowing of the seeds. The crop will be kept under constant observation from 
the pest appearance to maturity. The observations will be recorded at weekly intervals. The population of whitefly, Bemisia tabaci will be counted visually on whole plant in the initial stage and on three leaves i.e. one from top, middle and bottom of each tagged plant in later stage. For counting the whitefly population, the leaf will be held at the petiole by thumb and forefinger and twisted until the entire under side of leaf will clearly visible. The grain yield $(\mathrm{kg} / \mathrm{ha})$ of moth bean from each treatment was recorded and economics of different treatments were worked out. The data collected were transformed in to angular or square root value as per the standard requisites (Gomez and Gomez, 1984). Fipronil 5\%SC@ $2 \mathrm{ml} / \mathrm{kg}$ seeds,T8: Fipronil 5\%SC@4 ml/kg seeds and T9: Untreated control. All the agronomic practices were followed for raising the crop. Seed treatment from different insecticides was done before sowing of the seeds. The crop will be kept under constant observation from the pest appearance to maturity. The observations will be recorded at weekly intervals. The population of whitefly, Be- misia tabaci will be counted visually on whole plant in the initial stage and on three leaves i.e. one from top, middle and bottom of each tagged plant in later stage. For counting the whitefly population, the leaf will be held at the petiole by thumb and forefinger and twisted until the entire under side of leaf will clearly visible. The grain yield $(\mathrm{kg} / \mathrm{ha})$ of moth bean from each treatment was recorded and economics of different treatments were worked out. The data collected were transformed in to angular or square root value as per the standard requisites (Gomez and Gomez, 1984).

\section{RESULTS AND DISCUSSION}

Perusal of results presented in table 1 revealed that all the seed treatments were found significantly superior over control in reducing the whitefly, Bemisia tabaci population in moth bean. During the year 2012, seed treatment of thiomethoxam 35FS@5 g/ kg seeds was found to be most effective to manage the whitefly population which recorded only 0.24 white fly per leaf. During 2013 significantly lowest whitefly population

Table 1. Pooled efficacy of seed treatment on population of whitefly on moth bean.

\begin{tabular}{llllll}
\hline S. N. & Treatment & \multicolumn{3}{l}{ White fly/leaf } & \multirow{2}{*}{ Pooled } \\
\cline { 3 - 5 } & & $\mathbf{2 0 1 2}$ & $\mathbf{2 0 1 3}$ & $\mathbf{2 0 1 4}$ & \\
\hline 1 & Bifenthrin 10 EC@ 2 ml/kg seeds & $0.76(0.58)$ & $1.050 .61)$ & $1.12(0.76)$ & $0.97(0.65)$ \\
2 & Bifenthrin 10 EC@ 4 ml/kg seeds & $0.66(0.44)$ & $0.980 .46)$ & $1.01(0.53)$ & $0.88(0.47)$ \\
3 & Imidacloprid 600FS@ 3 g/kg seeds & $0.69(0.47)$ & $1.010 .53)$ & $1.06(0.63)$ & $0.92(0.54)$ \\
4 & Imidacloprid 600FS @ 5 g/kg seeds & $0.61(0.38)$ & $0.91(0.33)$ & $0.98(0.47)$ & $0.83(0.39)$ \\
5 & Thiomethoxam 35 FS@3g/kg seeds & $0.62(0.39)$ & $0.93(0.36)$ & $1.00(0.50)$ & $0.85(0.41)$ \\
6 & Thiomethoxam35 FS @ 5g/kg seeds & $0.49(0.24)$ & $0.89(0.29)$ & $0.96(0.43)$ & $0.78(0.32)$ \\
7 & Fipronil 5\%SC@ 2 ml/kg seeds & $0.81(0.66)$ & $1.11(0.73)$ & $1.15(0.83)$ & $1.02(0.74)$ \\
8 & Fipronil 5\%SC@ 4 ml/kg seeds & $0.62(0.38)$ & $0.94(0.39)$ & $1.02(0.56)$ & $0.86(0.44)$ \\
9 & Control & $0.90(0.82)$ & $1.24(1.03)$ & $1.35(1.33)$ & $1.16(1.06)$ \\
S.Em \pm & & 0.03 & 0.04 & 0.015 & 0.040 \\
C.D. at 5 \% & 0.10 & 0.12 & 0.047 & 0.11 \\
Y x T & - & - & - & NS \\
CV \% & & 8.67 & 11.23 & 7.49 & - \\
\hline
\end{tabular}

$* \sqrt{ } \mathrm{X}+0.5$ transformed values:-Figures in parenthesis are retransformed values.

Table 2. Pooled efficacy of seed treatment on seed yield of moth bean.

\begin{tabular}{llllll}
\hline \multirow{2}{*}{ S. N. } & Treatment & \multicolumn{3}{c}{ Yield (Kg/ha) } \\
\cline { 3 - 6 } & Bifenthrin 10 EC@ 2 ml/kg seeds & 330 & 248 & $\mathbf{2 0 1 4}$ & Pooled \\
\hline 1 & Bifenthrin 10 EC@ 4 m1/kg seeds & 355 & 315 & 444.36 & 303.55 \\
2 & Imidacloprid 600FS@ 3 g/kg seeds & 329 & 283 & 370.33 & 327.33 \\
3 & Imidacloprid 600FS @ 5 g/kg seeds & 408 & 418 & 475.86 & 438.77 \\
4 & Thiomethoxam 35 FS@3g/kg seeds & 347 & 296 & 407.33 & 349.78 \\
5 & Thiomethoxam35 FS @5g/kg seeds & 449 & 433 & 499.96 & 450.55 \\
6 & Fipronil 5\%SC@ 2 ml/kg seeds & 306 & 257 & 351.83 & 304.88 \\
7 & 359 & 355 & 388.86 & 367.56 \\
8 & Fipronil 5\%SC@ 4 ml/kg seeds & 299 & 187 & 259.20 & 248.22 \\
9 & Control & 20.07 & 6.07 & 17.16 & 14.79 \\
S.Em \pm & & 62.47 & 18.37 & 51.90 & 44.35 \\
C.D. at 5 \% & - & - & - & 41.66 \\
Y x T & & 10.20 & 10.88 & 8.87 & - \\
CV \% & & & & \\
\hline
\end{tabular}


was noticed in seed treatment of thiomethoxam 35FS (a) $5 \mathrm{~g} / \mathrm{kg}$ seeds (0.29/leaf) and was at par with thiomethoxam 35FS@5 g/kg seeds, imidacloprid 600FS@3 g/kg seeds, imidacloprid 600FS@ @ 5 g/kg seeds and fipronil 5\% SC@4 ml $/ \mathrm{kg}$ seeds. Similarly in pooled results also thiomethoxam 35FS@5 g/kg seeds maintained the trend and significantly reduced (0.32/leaf) the whitefly population which was at par with imidacloprid600FS@5 g/ kg seeds and fipronil 5\% SC @ 4 ml $/ \mathrm{kg}$ seeds. Similar results were obtained by Patel et al. (2012) who found the minimum white fly ( 0.49 white fly/leaf) population in thiamethoxam 70 ws @ $5 \mathrm{~g} / \mathrm{kg}$ seeds in cowpea. Panduranga et al. (2011) also reported that seed treatment with imidacloprid 70WS protect the mung bean crop from white flies. The results pertaining to grain yield of moth bean (table 2) revealed that significantly maximum yield was obtained in the treatment of thiomethoxam 35FS (a) $5 \mathrm{~g} / \mathrm{kg}$ seeds $(449 \mathrm{~kg} / \mathrm{ha})$ and it was at par with imidacloprid600FS@5 g/kg seeds (408 kg/ha)during 2012. In Kharif 2013, thiomethoxam 35FS@ 5 g/kg seeds $(433 \mathrm{~kg} / \mathrm{ha})$ was found superior as compared to the rest of the treatments. During 2014, highest yield was obtained in the seed treatment of thiomethoxam 35FS@ $5 \mathrm{~g} / \mathrm{kg}$ seeds. Similarly in pooled results, thiomethoxam 35FS@5 g/kg seeds was recorded higher seed yield $450.55 \mathrm{~kg} / \mathrm{ha}$, which was at par with imidacloprid 70 ws @ 5g/kg seeds (438.77kg/ha) and minimum seed yield was recorded in conrol (248.22 $\mathrm{kg} / \mathrm{ha})$. Similar results were obtained by Patel et.al. (2012), they found the maximum seed yield in seed treatment with imidacloprid 70 ws @ $5 \mathrm{~g} / \mathrm{kg}$ seeds which records cowpea grain yield $870 \mathrm{~kg}$ per hectare. The economics of various seed treatments (Table 3 ) revealed that the higher net gain was obtained in the treatment of thiomethoxam 35FS @ $5 \mathrm{~g} / \mathrm{kg}$ seeds (Rs. 9354/ha). While the higher ICBR was obtained in the treatment of imidacloprid 600FS @ $5 \mathrm{~g} / \mathrm{kg}$ seeds (1:37) and fipronil 5\% SC @ 4 ml $/ \mathrm{kg}$ seeds (1:37). On the basis of net gain and the efficacy of different seed treatments, thiomethoxam 35FS@5 g/kg seeds and imidacloprid 600FS @ $5 \mathrm{~g} / \mathrm{kg}$ seeds were found to be very effective to reduce the white fly incidence in moth bean.

\section{Conclusion}

Signicant differences were observed for management of white fly, Bemisia tabaci by seed treatment. Farmers are advised to treat the seed with Thiomethoxam35 FS@ $55 \mathrm{~g} / \mathrm{kg}$ seeds or Imidacloprid 600FS@ $95 \mathrm{~g} / \mathrm{kg}$ seeds before the sowing of seeds for the control of white fly in moth bean crop in arid region where the water scarcity is a major problems and get maximum yield of the moth bean.

\section{REFERENCES}

Anonymous, (2013). Agricultural Statistics, Directorate of Economics \& Statistics, Department of Agriculture \& Cooperation, Ministry of agriculture, Govt. of Iindia.

Anonymous, (2014). Commissionerate of Agriculture, Ra- 
jasthan, Jaipur.

Gomez, A.K. and Gomez, A.A. (1984). Statistical procedure for agricultural research. John Wiley \& Sons, Inc., Singapore.

Panduranga, G.S., Vijayalaxmi, K. and Reddy, K.L. (2011). Evaluation of insecticides for management of Bemisia tabaci and mymv disease in mungbean [Vigna radiate (L.) Wilczek]. Annals of Plant Protection Sciences, 19 (2):295-298.

Pareek, B.L., Sharma, R.C. and Yadav, C.P.S. (1983). Records of insect faunal complex on mothbean, Vigna aconitifolia (Jacq.) Marechal in semi-arid zone of Rajasthan. Bulletin of Entomology, 24 (1): 44-45.

Patel, P.S.; Patel I.S.; Panickar, B. and Ravindrababu, Y. (2012). Management of sucking pests of cowpea through seed treatment. Trends in Biosciences, 5(2):
138-139.

Puttaswami, Gowda, B.L.V. and Ali, T.M.M. (1977). Record of pests infesting mothbean, Phaseolus aconitifolia (Jacq.) a potential pulse crop. Curr. Res., 6 (4): 69-71.

Pareek, B.L., Sharma, R.C. and Yadav, C.P.S. (1983). Records of insect faunal complex on mothbean, Vigna aconitifolia (Jacq.) Marechal in semi-arid zone of Rajasthan. Bulletin of Entomology, 24 (1): 44-45.

Patel, P.S.; Patel I.S.; Panickar, B. and Ravindrababu, Y. (2012). Management of sucking pests of cowpea through seed treatment. Trends in Biosciences, 5 (2):138-139.

Puttaswami, Gowda, B.L.V. and Ali, T.M.M. (1977). Record of pests infesting mothbean, Phaseolus aconitifolia (Jacq.) a potential pulse crop. Curr. Res.,6 (4): 69-71. 